MARIA ANNA FURTAK

\title{
ST. HEDWIG PARISH IN DETROIT - ON THE EVENTS OF 1905 IN PRESS ARTICLES OF THAT TIME
}

At the beginning of the 20th century Detroit was rapidly developing and dominated by industry employing workers from all over the world. ${ }^{1}$ One of the groups in that multicultural melting pot were Poles, who had been arriving there since the 1850 s, were a constantly growing community, settling down in the same neighborhoods, which evolved in Polish districts, establishing their businesses and organisations. ${ }^{2}$ That mass of Roman-Catholic and same-ethnicity people (in 1900 about 50,000 people) required above all keeping their cultural identity, and the main solution for that was building churches led by a Polish priest. The end of 19th century and the beginning of the 20th was also a time of unease in American Catholic Church, in which context the case of St Hedwig parish in 1905 can be considered. ${ }^{3}$

Mgr Maria AnNa Furtak - The John Paul II Catholic University of Lublin, Faculty of Humanities, Institute of History; e-mail: furtakma@gmail.com. ORCID: https://orcid.org/0000-00024797-9135.

${ }^{1}$ Detroit's population rapid and multicultural growth is represented on a timeline: in 1870 almost half the population of 79,577 was born in a different country, in 1880 over 40 nationalities represented; in 1900 nearly 12\% of Detroit's population did not speak English; https://detroithistorical.org/ learn/timeline-detroit/industrial-detroit-1860-1900 [19.03.2020]; s. Mary Remigia NAPOLSKA, Polish immigrant in Detroit, "Polish American Studies," Vol. 2, No. 1/2, 1945, pp. 4-11.

2 P. TARAS, Polonia w Detroit: problem kulturowej tożsamości i społecznego awansu: socjologiczne studium społeczności etnicznej w USA, Warszawa 1989, p. 56.

${ }^{3}$ In the late 19th century among American bishops emerged an idea of liberalization of the US Church based on American society values - democracy, independence, and liberty enunciated by card. J. Gibbons, archbishops J. Ireland and J.J. Kene. Pope Leo XIII in the apostolic letter Testem benevolentiae (1899) condemned this idea. In those times, the Catholic Church was dominated by bishops of Irish origin, which caused many conflicts, e.g. establishing independent churches - see R. Niparko, Amerykanizm, in: Encyklopedia Katolicka, Vol. 1, Lublin 1973, col. 450-451; J.T. ELLIS, Kościót w Stanach Zjednoczonych od roku 1985, in: Historia Kościoła, translated T. Szafrański, Vol. 5, Warszawa 1985, pp. 200-208; R.M. LinkH, American Catholicism and European Immigrants (1900-1924), Staten Island 1975, pp. 19-26. 
In the early 1900s in Detroit there were 7 Polish churches, situated mainly in the southern part of the city. All these parishes were national (or personal), which means that were utterly initiated and organised by Poles, with a church building built at their own cost, led by a Polish priest, with teachings in the Polish language. Hence, parishioners as parish founders strived for independence and self-sufficiency, which sometimes caused conflicts with diocese authorities and parish priests. In a history of Polish Americans many cases can be found, when misunderstandings and arguments between parishioners and clergy led to longlasting clashes and even to establishing an independent Polish National Catholic Church (series of clergy-parishioners conflicts in Buffalo, Chicago, Scranton in $\left.1890 \mathrm{~s}^{4}\right)$. Less serious, but still significant were conflicts in Holy Trinity of Chicago, ${ }^{5}$ St. Hedwig in Chicago, ${ }^{6}$ St. Albertus in Detroit, ${ }^{7}$ and in St. Hedwig in Detroit which will be described in this article.

Detroit's St. Hedwig was the eighth Polish parish, opened because of the growth of the older St. Francis Parish, ${ }^{8}$ the process of its establishment and later turn of events was covered in detail by two major newspapers: Detroit Free Press ${ }^{9}$ and The Evening News, Detroit. ${ }^{10}$

About 1902, a district of later St. Hedwig Parish in Detroit at Junction Avenue started to be settled by Poles, mainly from Galicia. They attended St. Francis Church, ${ }^{11}$ but many of them wanted their own parish, and soon meetings were held on how to bring that idea to life. A group of 6 men (Jakub Kronk, Jan Koś, Józef

${ }^{4}$ H. Kubiak, Polski Narodowy Kościót Katolicki w Stanach Zjednoczonych Ameryki w latach 1897-1965: jego społeczne uwarunkowania i społeczne funkcje, Wrocław 1970; D.S. BuczeK, Kultura religijna Polonii. Analiza zagadnień, in: Polonia amerykańska. Przeszłość i współczesność, eds. H. Kubiak, E. Kusielewicz, T. Gromada, Wrocław 1988, pp. 293-325; P. Fox, The Polish National Catholic Church, Scranton 1961.

${ }^{5}$ G. Potaczala, Polacy na Trójcowie, Chicago 2007; Dzieje Parafii Świętej Trójcy 1873-1898, Chicago, IL 1898.

${ }^{6}$ History of All Saints Cathedral 1895-1995, Chicago 1995.

7 L.D. Orton, Polish Detroit and the Kolasinski Affair, Detroit 1981; E.A. SKendzel, Dominik Hipolit Kolasiński (1838-1898), "Studia Polonijne," Vol. 8, 1984, pp. 299-308; E. BoyEA, Father Kolasinski and the Church, "The Catholic Historical Review," Vol. 74, No. 3, 1988, pp. 420-439.

${ }^{8}$ News of the architects. Large church and several elegant residences are be built soon, "Detroit Free Press," 8.03.1903, p. 10.

${ }^{9}$ Detroit Free Press - the first daily paper issued in Detroit since 1835, https://detroithistorical. org/learn/encyclopedia-of-detroit/detroit-free-press [19.03.2020].

${ }_{10}$ The Evening News, Detroit - daily paper issued since $1873 \mathrm{https}: / /$ detroithistorical.org/learn/ encyclopedia-of-detroit/detroit-news [19.03.2020].

${ }^{11}$ St. Francis of Assisi Church and Parish was the third Polish parish established in 1889, see: Remembrance of the 100th Anniversary St. Francis Assisi Parish, Detroit, Michigan 1989. 
Kuroń, Michał Wójcik, Wawrzyniec Niziński, Józef Lula) ${ }^{12}$ took a lead by counting all families which would like to be a new parish's members and forming a committee, which would be in charge of collecting signatures in favor of an initiative. It turned out that about 300 families wanted to join a new parish in their district, so the committee asked the bishop John Samuel Foley ${ }^{13}$ to appoint a Polish priest. ${ }^{14}$ These committee activities were held in spite of the fact that at St. Francis Parish a new, bigger church was to be built. The compromise was made with Michigan Avenue as a boundary between parishes. ${ }^{15}$ Bishop Foley approved money collections were organized by parishioners for the second church, named in honor of St. Hedwig of Silesia. ${ }^{16}$

Rev. Francis Mueller, a Pole from Prussia raised in the US, and a professor in the Polish Seminary in Detroit was appointed rector of a new church on 3rd July 1903. His obligation was organizing a parish and building a St. Hedwig's church. ${ }^{17}$ He was enthusiastically accepted by parishioners, in that time of about 500 families focused on rapid completing their church building, as Detroit Free Press describes "they are all anxious to get a church erected before winter," which was to be built at the corner of Junction and Annexation Avenues..$^{18}$ Architects Kastler (Kessler) and Hunter made plans for a church and school building for St. Hedwig's parish. ${ }^{19}$ The church cornerstone was laid by bishop Foley on 6th December 1903 - this event was solemnly celebrated and attended by about 8,000 people - new parish members who expected the building completion by March 1904. ${ }^{20}$ It is interesting that the

${ }_{12}$ History of St. Hedwig Parish. Diamond Jubilee of St. Hedwig Parish 1903-1978; W. SMOŁCZYŃSKI, Przewodnik adresowy firm polskich w Detroit, Mich.: oraz Historya osady i parafii polskich w tem mieście. Książka pamiątkowa z życia polaków na obczyźnie, Detroit 1907, p. 95.

13 John Samuel Foley (1833-1918) - the fourth bishop of Detroit (1888-1918). He was born in Baltimore in 1833 in a family of Irish origin and ordained a priest in 1856. His brother was Bishop Thomas Foley, administrator of Chicago (1870-1879). He established a special seminary for the Poles (SS. Cyril and Methodius Seminary) and several polish parishes in Detroit. He died in 1918 - "Detroit" in the Catholic Encyclopedia, http://www.newadvent.org/cathen/04758b.htm [22.02.2020].

${ }^{14}$ Pamiętnik Jubileuszowy Parafii św. Jadwigi w Detroit 1903-1928.

${ }_{15}$ Church named, but no edifice. Secessionist of St. Francis puzzled by the bishop, "The Evening News, Detroit," April 2, 1903, p. 9.

${ }^{16}$ Ibid.

${ }^{17}$ Pamiętnik Jubileuszowy Parafii św. Jadwigi w Detroit 1903-1928.

${ }^{18}$ He will erect a new parish. Fr. John Mueller to be first pastor of st. Hedwig's, "Detroit Free Press," July 21, 1903, p. 5.

${ }_{19}$ News of the Architects. More Rigid Building Inspection Demanded, "Detroit Free Press," July 26, 1903, p. 9.

${ }^{20}$ Dedicated to God's service, "Detroit Free Press," Dec 7, 1903, p. 5; Poles there in great numbers, "The Evening News" [Detroit], Dec 7, 1903, p. 5. 
high cost of this undertaking (60,000 dollars) was not an obstacle for these people, in majority low paid workers.

After an enthusiastic beginning, when the church foundation and the walls to the first floor were completed, in January 1905 the problems started. The parish committee, led by John Kosch (Koś) did not agree with Rev. Mueller's decision on the building contract and the fact that all the bids for the work came to Rev. Mueller and "the pastor undertook to dictate just what bids should be accepted, he ignored the lowest bid offered, recommended the higher one (60,000 dollars)" as Detroit Free Press wrote. ${ }^{21}$

The committee did not want to approve that rev. Mueller was not born in the same province as the majority of parishioners - in Galicia, but in Prussian ruled territory, and because of this, his spoken language was inarticulate for Galicians. What is more, he used the English language in parish accounts making them unacceptable for non-English speaking committee members ${ }^{22}$ who could not check their correctness. Parish had a 40,000 dollar debt and all payments were made with checks, so ledger account could be kept - trustees objected to this. ${ }^{23}$ Rev. Mueller was disliked by some of his parishioners, who called him "Americanized Prussian Pole."24

The committee stated that the Rector should have obeyed because his salary and accommodation was paid by the parishioners. The conviction that the parish members have a decisive role in their parish life caused an urge to have a priest of their own choice. ${ }^{25}$ The committee chosen by parishioners consisted of 6 men: Lawrence Nizynski, Alex Czarnecki, Joseph Lula, Joseph Morance, Stanislaus Zelek, Anthony Wilczynski asked bishop Foley by petition Rev. Mueller to be removed. ${ }^{26}$ Bishop refused all their requests. He selected another committee according to the diocesan law and did not want to agree with parishioners' choice. ${ }^{27}$ What is important the trustees were the same people who had been aspiring to establish St. Hedwig parish from St. Francis. ${ }^{28}$

Meanwhile, Rev. Mueller was forced to leave a rented house, where he had been living since July 1903, and move to unfinished church building. ${ }^{29}$ That was inspired

\footnotetext{
${ }^{21}$ St. Hedwig Poles Scrapping again, "Detroit Free Press," April 7, 1904, p. 5.

22 Bishop to settle it, "Detroit Free Press," May 24, 1905, p. 11.

${ }^{23}$ St. Hedwig Poles scrapping again, "Detroit Free Press," April 7, 1905, p. 5.

${ }^{24}$ Bishop's edict stuns parish, "Detroit News," June 13, 1905, p. 5.

${ }^{25}$ Bishop to settle it, "Detroit Free Press," May 24, 1905, p. 1.

${ }^{26}$ St. Hedwig Poles Scrapping again, "Detroit Free Press," April 7, 1905, p. 5.

${ }^{27}$ Bishop to settle it, "Detroit Free Press," May 24, 1905, p. 11.

${ }^{28}$ Mean war to knife, "Detroit Free Press," June 19, 1905, p. 3.

${ }_{29}$ Bishop to settle it, "Detroit Free Press," May 24, 1905, p. 1.
} 
by one of the trustees, who tried to expel the Reverend from the parish. Despite trustees' hostility toward the priest, bishop Foley was satisfied with Mueller's work and it seemed appropriate to appoint him because he was a person not involved in any faction..$^{30}$ The bishop gave the trustees ignoring him and his guidelines an ultimatum: the parish must accept the Rev. Mueller as their rector and turn back parish fund books "under the pain of excommunication." Until the reconciliation, the bishop ordered the church to be locked and any church service could be held..$^{31}$

The trustees did not want to obey the bishop's warning; after a meeting with parish members they decided to keep parish account books and confirmed their postulates. The bishop's answer was strict: on 15th June 1905 the document of excommunication was nailed to St. Hedwig's church main door:

after repeated and formal applications for the possession of the account books of St. Hedwig church, now held in your hands and after a constant refusal to accede to said applications I, Bishop do hereby decree excommunication (nominatim) from the catholic church (...) and herewith that all those who by active co-operation or support endeavour to abet or sustain said contumacious and excommunicated persons will incur the same penalty.

Given at Detroit this 15 th day of June $1905 .{ }^{32}$

Five trustees were excluded from Catholic Church community and the parish was under interdict what meant any religious service could be held in the church: "In it are mentioned the names of the five parishioners who have been acting as trustees and the letter also states that ban applies to all persons of the parish who gave active cooperation to those directly excommunicated." ${ }^{33}$ The unfinished church building was under the control of bishop who had arranged with the Redemptorist Fathers to answer sick calls in St. Hedwig Parish and to conduct ceremonies. ${ }^{34}$

The excommunication document was destroyed by disgruntled parishioners soon, who cut it with knives, and a group of 200 people gathered at the church door for discussion. They were dispersed by the police. ${ }^{35}$

The aspiration towards independence made that "excommunicated declared they will not give the books to the bishop without direct instructions from the parish

${ }^{30}$ Bishop to settle it, "Detroit Free Press," May 24, 1904, p. 11.

${ }^{31}$ Bishop's edict stuns parish, "Detroit News," June 13, 1905, p. 5.

32 The excommunication document was cited in "The Evening News, Detroit," June 16, 1905, p. 1.

${ }^{33}$ Excommunicated, "Detroit Free Press," June 16, 1905, p. 12; St. Hedwig Church under police guard, "The Evening News, Detroit," June 16, 1905, pp. 1-16.

${ }^{34}$ Will close church, "Detroit Free Press," June 15, 1905, p. 5.

${ }^{35}$ Excommunicated, "Detroit Free Press," June 16, 1905, p. 12. 
"the argument used by the trustees is that neither the bishop or any priest has a right to handle the finances of the parish." ${ }^{\prime 36}$

There was some risk that a new independent church will be established, however "neither bishop nor trustees didn't want to obey - the only solution seems to be in giving a parish another pastor, but the bishop would insist his instructions to be obeyed ant the books of the parish be turned over to him." ${ }^{\prime 37}$

Rev. Mueller and Bishop Foley had support from other Polish priests and the bishop's demands were supported by local police - Sheriff Burns and his deputies demanding parish books from trustees and patrolling the parish neighborhood streets. They were send to regain the parish books, but learnt that "the parish has them." It meant that it was impossible to find out which member of 700 parishioners has the books "the books are being passed from one member to another so that nobody can tell any given time just where they are." ${ }^{38}$ The trustees tried to find another solution by choosing a new committee, but bishop decision was headstrong that the old committee must give up the books. Although not all parishioners were against Rev. Mueller, the majority said: "We will stay just where we are until we get a Galician priest." 39

Parishioners became tired of the "turbulent state of the affairs," because everything resulted from "the machinations of one man, who is alleged to have wanted to get on the church committee and handle some of the church funds." ${ }^{40}$

On 18 July 1905 a parish meeting was held. John Kosch (John Kosch "a philosopher and revolutionary leader" as described him Detroit Free Press) gave a speech, Rev. Mueller listened to parishioner's demands but group of 690 men, all members of St. Hedwig's met in a hall near the church and voted unanimously to stand by the trustees, who refused to give books to the bishop or the priest. There was no acceptance for trustees to resign "we won't let you resign, and if you do, you will have to settle with us." 41

The trustees agreed to return books under condition the bishop agree to remove the rev Mueller "but the bishop cut the interview short with the declaration that there could be no communication until the books of the church had been turned over to Attorney Denis B. Hayes." "Church is closed and would stay closed until

${ }^{36}$ Ibid.

37 Ibid.

${ }^{38}$ Parish has books, "Detroit Free Press," June 26, 1905, p. 3.

39 Little priest will win out, "The Evening News, Detroit," June 17, 1905, p. 1.

${ }^{40}$ St. Hedwig's men show first sign of surrender, "The Evening News, Detroit," June 18, 1905, p. 1.

${ }^{41}$ Rev. Mueller faced his flock, "The Evening News, Detroit," June 19, 1905, p. 5; Mean war to knife, "Detroit Free Press," June 19, 1905, p. 3. 
submission to my orders was shown" the bishop said. Parish borrowed 30 or 35 thousand dollars from a local savings bank at percent interest, and the committee declared that the parish would no longer pay the interest on this amount. ${ }^{42}$

"We would rather see it (the church) sold, than have Rev. Mueller for pastor any longer" 43 the only thing we're sure of is that that man is no priest for this parish." 44 However, one of the parishioners said that not all of them wants a Galician priest, because in the parish were Poles from Prussia, Russia and Galicia and "all they wanted was a priest who knows something." 45

There was a huge hope that Archbishop Franciszek Albin Symon who was on his visit in the USA would solve the problem and give St. Hedwig Parish a new priest. ${ }^{46}$ Parishioners decided to wait for archbishop Symon and ask him for mediation after submitting the matter to him. They stated that "if he sides with bishop Foley it is possible that the parish will give in and let the books out of its hands."

Many parishioners did not want to have their 60,000 dollars property remain unused and a dead loss on their hand. ${ }^{47}$

"The bishop is wrong. He has no right to keep us out of the church. it is our church. We built it. we have been dissatisfied with the priest ever since he came here[...] The bishop wants to be an absolute ruler of the church - no committee." ${ }^{48}$ Because of that, there was a serious risk of forming an independent church and rumors appeared that an independent priest was ready to assume charge. ${ }^{49} \mathrm{It}$ was ever more serious when parishioners threatened that in case of Archbishop Symon's help refusal, they would appeal to the Polish Bishop Kozlowski of Chicago. ${ }^{50}$

Archbishop Symon arrived in Detroit on 13th August 1905 and the city was one of the stops during his trip to the USA. He celebrated masses and gave speeches,

${ }^{42}$ No books, no change, "Detroit Free Press," June 29, 1905, p. 5.

${ }^{43}$ Ibid.

${ }^{44}$ Torn almost to shreds, "Detroit Free Press," July 2, 1905, p. 8.

${ }^{45}$ Settlement is near, "Detroit Free Press," July 31, 1905, p. 5.

46 St. Hedwig's quiet, "Detroit Free Press," June 17, 1905, p. 12; Everything is Quiet, "Detroit Free Press," June 20, 1905, p. 2; Franciszek Albin Symon (1841-1918) - Roman Catholic priest, bishop o Mohylew, titular archbishop of Attalia, bishop of Płock (1897-1901), in 1905 the Apostolic visitor to Polish parishes in America, in: P.E. Herod, S. Tylus, Symon Franciszek Albin, in: Encyklopedia Katolicka, Vol. 18, Lublin 2013, col. 1314-1315.

47 Debated two hours, "Detroit Free Press," July 3, 1905, p. 5.

48 Seeking converts, "Detroit Free Press," July 5, 1905, p. 5.

49 Independent Church, "Detroit Free Press," July 24, 1905, p. 5; Fr. Mueller wants to quit, "Detroit News," July 27, 1905, p. 1.

${ }^{50}$ St. Hedwig Church under police guard, "The Evening News, Detroit," June 16, 1905, p. 1 and p. 16. 
delivering sermons in several polish churches (St. Casimir, St. Francis, St. John Cantius, St. Stanislaus). His visit aimed to "see the country and its people" and had nothing to do with St. Hedwig parish conflict. ${ }^{51}$ Also, any intervene in the issue was impossible due to canon law - all prerogatives were in diocesan bishop's hands, in bishop Foley's in that case. Despite that fact, a delegation from St. Hedwig to archbishop Symon ask him for the help and possibility of choosing priest of their choice. ${ }^{52}$ He said that he could not comply with their demands but advised a compromise: the parish would get appointed a new pastor and the committee would give books back. ${ }^{53}$

This solution seemed to be appropriate for both sides. Archbishop Symon's role as a conciliator helped to stifle the conflict. Both St Hedwig parishioners and bishop Foley did not want a longer stubborn argument.

Achieving compromise, Detroit's Bishop Foley decided to reopen St. Hedwig's Church, cancel the interdict, and take the excommunication from the committee. On 27 August 1905 a church opening was celebrated with Symon attending, who came from Pittsburgh. ${ }^{54}$ In "solemn high mass sung by bishop Foley closed one of the fiercest factional fights ever known in a Polish church in Detroit" 55 and "he was very enthusiastic about his now reconciled parish." 56 Rev. Józef Bieja SJ was temporarily installed as a pastor and Fr. Karol Janowski as an administrator till 6 October 1905 when Fr. Bartłomiej Szczerba OMC was appointed a new pastor. $^{57}$

Reopening of St. Hedwig Church was a notable event, for all Detroit's society, not only Polish. The conflict engaged two important local newspapers which were covering the events successively and in detail. Almost everyday articles on St. Hedwig's argument were published in the press. It may indicate that the Polish ethnic group, although non-English speaking in the majority, was considered a true part of Detroit's society. What is interesting, Silver Jubilee Book of St. Hedwig doesn't mention the details of the 1905 conflict which could be traced back only by journal accounts. Neither W. Kruszka in his Historya polska w Ameryce describes the St. Hedwig parish case of 1905, despite he mentions parish's financial (income

${ }^{51}$ Priests welcome archbishop with joyous arclaim, "The Evening News, Detroit," August 13, 1905, p. 5; Simon takes a neutral stand, "The Evening News, Detroit," August 14, 1905, p. 5.

52 To hold aloof, "Detroit Free Press," August 14, 1905, pp. 1 and 3.

53 Church trouble compromised, "The Evening News, Detroit," August 18, 1905, p. 7.

54 Opens new era of St. Hedwig's, "The Evening News, Detroit," August 27, 1905, p. 5.

55 Joy at St Hedwig's, "The Evening News, Detroit," August 28, 1905, p. 5; Dove of peace lights on tower of St Hedwig's, "Detroit Free Press," August 28, 1905, pp. 1-2.

56 All happy at St. Hedwig 's, "Detroit Free Press," September 4, 1905, p. 5.

${ }_{57}$ Pamiętnik Jubileuszowy Parafii św. Jadwigi w Detroit 1903-1928. 
and debt) and describes parish school run by Felician sisters in $1907 .{ }^{58}$ Przewodnik adresowy firm polskich $w$ Detroit, Mich.: oraz Historya osady i parafii polskich w tem mieście. Książka pamiątkowa z życia polaków na obczyźnie, rok 1907 gives an account on these events calling them "a small commotion." 59

Arguments between clergymen and parishioners in Polish American history were not unprecedented although. As mentioned above, the most severe conflicts led to establishing the Polish National Catholic Church, completely independent of Roman-Catholic Church structures and to many other complicated situations. Poles arriving in the US in the second half of the 19th century and at the beginning of the 20th encountered different social and economic conditions than in partitioned Poland. On American soil, they could decide themselves of every aspect of life, also in parish establishing questions. They could be independent founders and builders of their parish, so they sought for in the control over its income, accounts, and expenses, which was understandable as parishioners invested their hard-earned money. According to this, they requested to choose which saint would be a parish patron, a priest who would minister as a pastor, or what would be the parish ownership. ${ }^{60}$ In the case of St. Hedwig parish is visible how an urge of having an appropriate priest was important. Every detail like a place of birth or spoken dialect was crucial - the laity wanted to decide on every aspect of their parish life, even if their decisions were not in accordance with the Canon Law. ${ }^{61}$

On the other hand, conflicts could be created because of the American hierarchy attitude - many bishops were opposed to nationalization endeavors trying to make American Catholic Church more homogenous and united. They pointed out the necessity of Americanization and assimilation of all immigrants, because of the superior role of the faith which was more important than "flesh and blood." ${ }^{\prime 2}$ What

${ }_{58}$ W. KruszKa, Historya polska w Ameryce, Vol. 11, Milwaukee 1907, p. 204.

59 W. SмolCZYŃski, Przewodnik adresowy firm polskich w Detroit, Mich.: oraz Historya osady i parafii polskich w tem mieście. Książka pamiątkowa z życia polaków na obczyźnie, Detroit 1907, pp. 95-96.

${ }^{60}$ E. Boyea, Father Kolasinski and the Church of Detroit, "The Catholic Historical Review," Vol. 74, No. 3, 1988, p. 420; L. Woodcock Tentler, Who is the Church? Conflict in a Polish Immigrant in late 19th Century Detroit, "Comparative Studies in Society and History," Vol. 25, No. 2, 1983, p. 245; A. BRożek, Polonia amerykańska 1854-1939, Warszawa 1977, pp. 95-98.

${ }^{61}$ Similar situation at Chicago's Immaculate Conception of Blessed Virgin Mary Parish - parishioners wanted their priest, some Silesian born parishioners moved away when the bishop refused any requests - Pamiętnik Złotego Jubileuszu Parafii Niepokalanego Poczęcia N.M.P., Chicago 1882-1932.

62 T.I. Monzell, The Catholic Church and Americanization, "Polish American Studies," Vol. 26, No. 1, 1969, pp. 2-5; A. WALASZEK, Kościót, etniczność, demokratyzacja, "Studia Migracyjne - Przegląd Polonijny,” Vol. 41, No. 1, 2016, pp. 16-17. 
is more, the American hierarchy, despite ethnic diversity of the society, was dominated by Irishmen. This caused many protests of Catholics of other nationalities urging to have their representative in the episcopacy. ${ }^{63}$

American bishops were opposed also to appointing bishop a Polish priest for a long time because they were afraid of appealing to him by Polish parishioners when some conflicts or misunderstanding would occur between them and the local bishop. ${ }^{64}$ That turned out to be true in St. Hedwig parish case when parishioners looked for a Polish bishop help opposing their bishop, who was American-born Irishman. ${ }^{65}$

L. Woodcock Tentler in the article Who is the Church? Conflict in a Polish Immigrant in late 19th Century Detroit states that Polish parishes were more prone than other ethnic groups to serious conflicts with Church hierarchy. It could be caused by the ignorance of the Canon Law or some theological questions. An interesting fact is they were widely joined by women. ${ }^{66}$

In the case of American church hierarchy and laity clashes often the only solution was an interdict for churches and excommunications for disobedient parishioners. In some cases it had to be compromised by Rome (e.g. in Holy Trinity of Chicago case) ${ }^{67}$ Because of that some conflicts lasted many years (e.g. Holy Trinity, Chicago - 18 years; St. Albertus, Detroit -9 years) during which churches were closed, and any religious services could not be held there. In most cases, these misunderstandings were stifled, but in several - led to establishing an independent Polish National Church.

The conflict in St. Hedwig parish, Detroit of 1905 can be considered one of the highlights of Polish history in Detroit and the United States. It shows how full of life and independence willing Polish immigrants were and that was a quality which helped them survive in a foreign country. Despite it is less known than St. Albertus Kolasinski Affair it is still important for understanding Polish immigrants' mentality, their solidarity and strive for independence and is an important part of Roman Catholicism in American history.

${ }^{63}$ Historia Kościoła, Vol. 5, pp. 200-208.

${ }^{64}$ T.I. Monzell, The Catholic Church and Americanization, p. 4.

${ }^{65}$ On Irish domination in American Roman Catholic Church and its relations with Polish Catholics in: A. BrożeK, Polonia amerykańska 1854-1939, pp. 95-98; D.S. BuCzeK, Kultura religijna Polonii, pp. 298-303.

${ }^{66}$ L. Woodcock Tentler, Who is the Church, pp. 243-244.

${ }^{67}$ Dzieje Parafii Świętej Trójcy 1873-1898, Chicago, IL 1898. 


\section{BIBLIOGRAPHY}

Boyea E., Father Kolasinski and the Church, "The Catholic Historical Review," Vol. 74, No. 3, 1988, pp. 420-439.

BRożEK A., Polonia amerykańska 1854-1939, Warszawa: Interpress 1977, pp. 95-98.

BuczeK D.S., Kultura religijna Polonii. Analiza zagadnień, in: Polonia amerykańska. Przeszłość i współczesność, eds. H. Kubiak, E. Kusielewicz, T. Gromada, Wrocław: Zakład Narodowy im. Ossolińskich 1988.

Ellis J.T., Kościół w Stanach Zjednoczonych od roku 1985, in: Historia Kościoła, translated T. Szafrański, praca zbior., Vol. 5, Warszawa: PAX 1985.

Fox P., The Polish National Catholic Church, Scranton: School of Christian Living 1961.

Herod P.E., Tylus S., Symon Franciszek Albin, in: Encyklopedia Katolicka, Vol. 18, Lublin 2013, col. 1314-1315.

KRUSZKa W., Historya polska w Ameryce, Vol. 11, Milwaukee: Drukiem Spółki Wydawniczej Kuryera 1907.

KubiaK H., Polski Narodowy Kościół Katolicki w Stanach Zjednoczonych Ameryki w latach 1897-1965: jego społeczne uwarunkowania i społeczne funkcje, Wrocław: Zakład Narodowy im. Ossolińskich, Wydawnictwo Polskiej Akademii Nauk 1970.

LINKH R.M., American Catholicism and European Immigrants (1900-1924), Staten Island, New York: Center for Migration Studies 1975, pp. 19-26.

Monzell T.I., The Catholic Church and Americanization, "Polish American Studies," Vol. 26, No. 1, 1969.

NAPOLSKa M.R., Polish immigrant in Detroit, "Polish American Studies," Vol. 2, No. 1/2, 1945.

NiPARKo R., Amerykanizm, in: Encyklopedia Katolicka, Vol. 1, Lublin 1973, col. 450-451.

OrTON L.D., Polish Detroit and the Kolasinski Affair, Detroit: Wayne State University Press 1981.

Potaczala G., Polacy na Trójcowie, Chicago 2007.

Skendzel E.A., Dominik Hipolit Kolasiński (1838-1898), "Studia Polonijne,” Vol. 8, 1984, pp. 299-308.

TARAs P., Polonia w Detroit: problem kulturowej tożsamości i społecznego awansu : socjologiczne studium społeczności etnicznej w USA, Warszawa: Pallottinum 1989.

WalaszeK A., Kościół, etniczność, demokratyzacja, "Studia Migracyjne - Przegląd Polonijny," Vol. 41, No. 1, 2016, pp. 16-17.

Woodcock Tentler L., Who is the Church? Conflict in a Polish Immigrant in late 19th Century Detroit, "Comparative Studies in Society and History," Vol. 25, No. 2, 1983, p. 245.

\section{Sources}

Dzieje Parafii Świętej Trójcy 1873-1898, Chicago, IL 1898.

History of St. Hedwig Parish. Diamond Jubilee of St. Hedwig Parish 1903-1978.

Pamiętnik Jubileuszowy Parafii św. Jadwigi w Detroit 1903-1928. 
Pamiętnik Złotego Jubileuszu Parafii Niepokalanego Poczęcia N.M.P., Chicago 1882-1932. Remembrance of the 100th Anniversary St. Francis Assisi Parish, Detroit, Michigan 1989. SmoŁcZYŃski W., Przewodnik adresowy firm polskich w Detroit, Mich.: oraz Historya osady i parafii polskich w tem mieście. Książka pamiątkowa z życia Polaków na obczyźnie, Detroit 1907.

\section{Press Articles}

"Detroit Free Press":

March 8, 1903; July 21, 1903; Dec 7, 1903; April 7, 1904; May 24, 1905; May 24, 1904; April 7, 1904; May 24, 1905; June 15, 1905; June 16, 1905; June 17, 1905; June 19, 1905; June 20, 1905; June 26, 1905; June 29, 1905; July 2, 1905; July 3, 1905; July 5, 1905; July 24, 1905; July 31, 1905; August 14, 1905; August 28, 1905; September 4, 1905.

"The Evening News, Detroit":

April 2, 1903; Dec 7, 1903; June 13, 1905; June 13, 1905; June 16, 1905; June 17, 1905; June 18, 1905; June 19, 1905; July 27, 1905; August 13, 1905; August 14, 1905; August 18, 1905; August 27, 1905; August 28, 1905.

\section{ST. HEDWIG PARISH IN DETROIT \\ - ON THE EVENTS OF 1905 \\ IN PRESS ARTICLES OF THAT TIME}

\section{Summary}

The aim of the article is to describe a St. Hedwig Detroit conflict of 1905. It was one of the Polish American history events, when a group of parishioners disobeyed their pastor and the local bishop. The conflict was covered in detail by two influential journals: Detroit Free Press and The Evening News, Detroit. The article focuses on the major events of the conflict beginning with establishing the St. Hedwig Parish in Detroit in 1903, a clash between parish trustees and the pastor, excommunication of disobedient trustees by Bishop John Samuel Foley and reopening the church in August 1905. That part of St. Hedwig Parish history shows how important was the parish for the community Polish immigrants community, what was their mentality and attitude towards American reality and Roman Catholic Hierarchy in the USA. The St. Hedwig conflict of 1905 is one of the similar events which occurred in at the turn of 19th and 20th century among Polish Americans and the American Church.

Keywords: American Polonia; Detroit's Polonia; Americanization; Catholic Church in Detroit 


\section{PARAFIA ŚW. JADWIGI W DETROIT \\ - O WYDARZENIACH Z 1905 R. W ARTYKUŁACH ÓWCZESNEJ PRASY}

\section{Streszczenie}

Celem artykułu jest przedstawienie konfliktu w parafii św. Jadwigi w Detroit w 1905 r. Jest to jeden z epizodów historii Polonii amerykańskiej, kiedy grupa parafian sprzeciwiła się przeciwko proboszczowi i lokalnemu biskupowi. Konflikt był opisywany przez dwie wpływowe gazety - "Detroit Free Press" i "The Evening News: Detroit". Artykuł skupia się na jego głównych wydarzeniach, począwszy od ustanowienia parafii w 1903 r., poprzez zatarg między komitetem parafialnym a proboszczem, ekskomunikę nieposłusznych parafian przez biskupa J.S. Foleya, po ponowne otwarcie kościoła w sierpniu 1905 r. Ten fragment historii parafii św. Jadwigi pokazuje, jak ważna była parafia dla społeczności polskich imigrantów, jaka była mentalność i nastawienie wobec amerykańskiej rzeczywistości i rzymskokatolickiej hierarchii w USA. Konflikt z 1905 r. jest jednym z podobnych wydarzeń, mających miejsce na przełomie XIX i XX wieku wśród Polonii amerykańskiej i tamtejszego Kościoła.

Słowa kluczowe: Polonia amerykańska; Polonia w Detroit; amerykanizacja; Kościół katolicki w USA 